\title{
Infection of dogs with Echinococcus granulosus: causes and consequences in an hyperendemic area
}

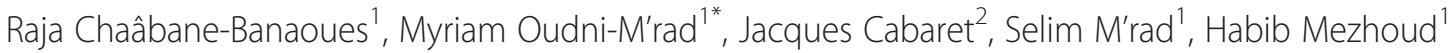 \\ and Hamouda Babba ${ }^{1,3}$
}

\begin{abstract}
Background: Tunisia is a hyper endemic country for human echinococcosis. The infection is transmitted via the eggs of Echinococcus granulosus which are passed in the faeces of the definitive canid host.

Methods: This study evaluated the contamination rate of the dog faeces in different climatic conditions at eight different geographic regions throughout Tunisia. Dog faecal samples were collected from the soil and the Echinococcus eggs were identified using microscopic and molecular (Eg1121/1122 PCR, Egss1 PCR and Nad1 P(R-RFLP) tools.

Results: The contamination index of dog faeces by E. granulosus eggs ranged from $8.3 \%$ to $41.3 \%$ depending on the region. Comparisons of the dog faecal contamination rate against human incidence found them to be independent. Neither human prevalence nor dog contamination index appeared to be related to climatic conditions or geographic characteristics. The genetic variability of $E$. granulosus samples was different within each region but was not related to geographic distance which is indicative of local divergent evolutions rather than isolation by distance.
\end{abstract}

Conclusions: A high environmental dog contamination index does not necessarily correspond to high prevalence in humans as transmission is strongly linked to human behavior and hygiene.

Keywords: Echinococcus granulosus, Dog faecal sample, Genetic variability, Environmental contamination, G1 genotype, Tunisia

\section{Background}

Echinococcosis is a widespread zoonotic parasitic disease which has major medical and socio-economic costs for humans and also threatens livestock productivity [1,2]. The causal pathogen, Echinococcus granulosus, parasitizes canids as its definitive hosts where the adult cestode inhabits the small intestine. Herbivores act as the intermediate hosts for the parasitic larval stage (metacestode) which is most commonly found in the host lungs and/or liver [3]. Human contamination occurs following the ingestion of taeniid eggs (or eggs reduced to embryophores)

\footnotetext{
* Correspondence: myriam.mrad@gnet.tn

'LP3M: Laboratoire de Parasitologie-Mycologie Médicale et Moléculaire, LR12ES08, Faculté de Pharmacie, Université de Monastir, 1 rue Avicenne, Département de biologie clinique B, 5000 Monastir, Tunisie

Full list of author information is available at the end of the article
}

through contaminated food, essentially vegetables and water [4] or by direct contact with contaminated dogs that retain eggs on their coat [5]. This leads to the development of cystic echinococcosis (CE). Tunisia is considered as an echinococcosis endemic region with an annual surgical incidence $(S I)$ of 12.6 cases per 100,000 inhabitants $(S I=12.6)$ [6] and approximately US\$ 10-19 million losses annually in both humans and animals [7]. Other Mediterranean countries such as Algeria $(S I=3.6-4.6)$, Libya $(S I=$ $4.2)$, Morocco $(S I=4.55)$, Italy $(S I=1.6)$, Spain $(S I=0.36)$, Greece (0.2) and France $(S I=0.1)$ have a lower surgical incidence [8-10]. However, the endemic status in Tunisia differs from one region to another. Some areas have been defined as hyperendemic $(S I>22.6)$ such as the Westnorthern regions of Kasserine and Kef, others as mesoendemic $(7.5<S I<15)$ such as the eastern region of Sousse 
and the region of Metlaoui situated in the south of Tunisia, and finally some as hypoendemic regions $(S I<$ 7.5) for the east-central region of Monastir, the south eastern regions of Zarsis, Djerba and Tataouine [6]. E. granulosus is a complex in which four or five cryptic species are intermixed. Thus, E. granulosus sensu lato was split into E. granulosus sensu stricto (genotypes G1 to G3), E. equinus (genotype G4), E. ortleppi (genotype G5), E. canadensis (genotypes G6 to G10) and Echinococcus felidis (lion strain) [11-13]. Only four genotypes have been described in Tunisia: the G1 genotype in humans, sheep, cattle and dromedaries [14,15], the G6 genotype in the Southern dromedaries [16], the G3 genotype in one cattle and one human isolate [16] and the G4 genotype in donkeys [17]. $\mathrm{CE}$ was reported in livestock and the prevalence of infection was $16.42 \%, 8.56 \%, 5.94 \%$ and $2.88 \%$ in sheep, cattle, dromedaries and goats respectively [18]. In Tunisia, the canine population is composed essentially of stray and semi-stray dogs (free-roming dogs which are fed by an owner), and rarely receives deworming treatment [19]. In rural areas, $80 \%$ of households own at least one dog. The canine density is one per 3.0 to 5.5 inhabitants. There are 7 to 30 dogs per $\mathrm{km}^{2}$ according to the regions [20]. A high prevalence of $E$. granulosus infection has been reported in Tunisian dogs ranging from 19 to $45.7 \%$ in function of the regions $[21,22]$. Although the infection is essentially propagated by dogs in areas where they are kept at home, the persistence of the parasite life cycle is linked to the durability of the E. granulosus eggs in the environment in places where stray dogs are a majority. The eggs remain infective to humans and the intermediate hosts for a long time (nearly four years) after having been deposited onto the soil and under different climatic conditions [23]. Determining the prevalence at which eggs are shed into the environment and their capacity to survive is fundamental to ascertain the real endemic status of echinococcosis in an area $[24,25]$. In dogs, the prevalence is suggested to be high (up to 65\%) in most Mediterranean countries [26]. However, these calculations were based on worms collected at necropsy from a limited number of dogs resulting in large confidence intervals. For example, a prevalence of $59 \%(46-71 \%)$ was detected in Morocco [27] and 7\% (3-17\%) in Tunisia-Sidi Bouzid [19]. Several techniques exist to assess the prevalence of E. granulosus in dogs including detection of worm antigen in faeces (coproantigen) [28], worms at necropsy [29] or direct examination of eggs in dog faeces [30]; however, these may vary in their estimates of prevalence. The direct sampling of dog faeces represents a relatively strong diagnostic tool as the taeniid eggs are easily recognized by light microscopy and molecular tools permit the specific identification of $E$. granulosus [31-33]. Although several epidemiological studies were performed on prevalence in necropsied dogs in Tunisia $[21,22]$ no information on the actual contamination of the environment by E. granulosus eggs is available. Our objectives were to: 1 ) assess the contamination index of $E$. granulosus eggs in dog faeces in regions of differing endemicity in Tunisia in order to determine the level of environmental contamination; 2) explore factors which may explain differences in the contamination index of dogs between regions including: environmental influences on egg development, the density of intermediate hosts and the possibility of worm transfer between regions as based on the genetic variability, 3) and finally relate the human incidence with dog contamination index.

\section{Methods}

\section{Sampling of dog faeces}

One thousand ninety five dog faecal samples were collected from four different climatic zones in Tunisia (Figure 1): Kef (sub-humid), Monastir and Sousse (semiarid), Metlaoui, Kasserine, Zarzis and Djerba (arid), and Tataouine (desert). These are all rural areas where livestock-farming occurs and the presence of stray and semi-feral dogs was observed. Forty samples were collected from a proportion of the faeces observed over a soil surface of $200-400 \mathrm{~m}^{2}$ on each location. The sampling was not related to a number of individual dogs but intended to represent the available eggs of Echinococcus granulosus on the area. Several sites were visited for each region (1-5) and collected during the Spring and Summer. The faecal samples were frozen at $-80^{\circ} \mathrm{C}$ for 7 days in order to partially inactivate infective stages of the parasites [34] and then stored at $-20^{\circ} \mathrm{C}$ until use. The parasite eggs were recovered from faecal samples using a flotation technique in modified Sheather's solution (specific gravity: $d=1.27$ ) followed by centrifugation at $1200 \mathrm{x} \mathrm{g}$ [35]. The taeniid eggs were subsequently identified morphologically [36]. The eggs were collected, out from the coverslip, using a $0.9 \% \mathrm{NaCl}$ solution and stored at $-20^{\circ} \mathrm{C}$. Nevertheless, the taeniid eggs are morphologically indistinguishable and the E. granulosus egg identification requires the use of PCR technique [31]. The sampling was not affecting dogs or their owner since they were collected in the wild and thus no special notification to an ethical committee was required.

\section{DNA extraction}

An alkaline lysis was performed to destroy the embryophore's rigid shell [37]. Briefly, $14 \mu \mathrm{l}$ of DTT (dithiothreitol) $(1 \mathrm{~mol} / \mathrm{l})$ and $50 \mu \mathrm{l}$ of $\mathrm{KOH}$ (potassium hydroxide) $(1 \mathrm{~mol} / \mathrm{l})$ were added to $100 \mu \mathrm{l}$ of egg suspension. The sample was heated at $65^{\circ} \mathrm{C}$ for one hour then neutralized with $120 \mu \mathrm{l}$ of Tris- $\mathrm{HCl}(\mathrm{pH} 8.3,2 \mathrm{~mol} / \mathrm{l})$ and $10 \mu \mathrm{l}$ of $\mathrm{HCl}(10 \mathrm{M})$. One hundred $\mu \mathrm{l}$ of lysis solution (Tris- $\mathrm{HCl}$ $50 \mathrm{mmol} / \mathrm{l}, \mathrm{pH} 8, \mathrm{NaCl} 100 \mathrm{mmol} / \mathrm{l}$, EDTA $50 \mathrm{mmol} / \mathrm{l}$, $\mathrm{pH} 8$ and SDS 1\%) and $10 \mu \mathrm{l}$ of Proteinase K (Invitrogen) $(20 \mathrm{mg} / \mu \mathrm{l})$ were added to the sample and incubated 


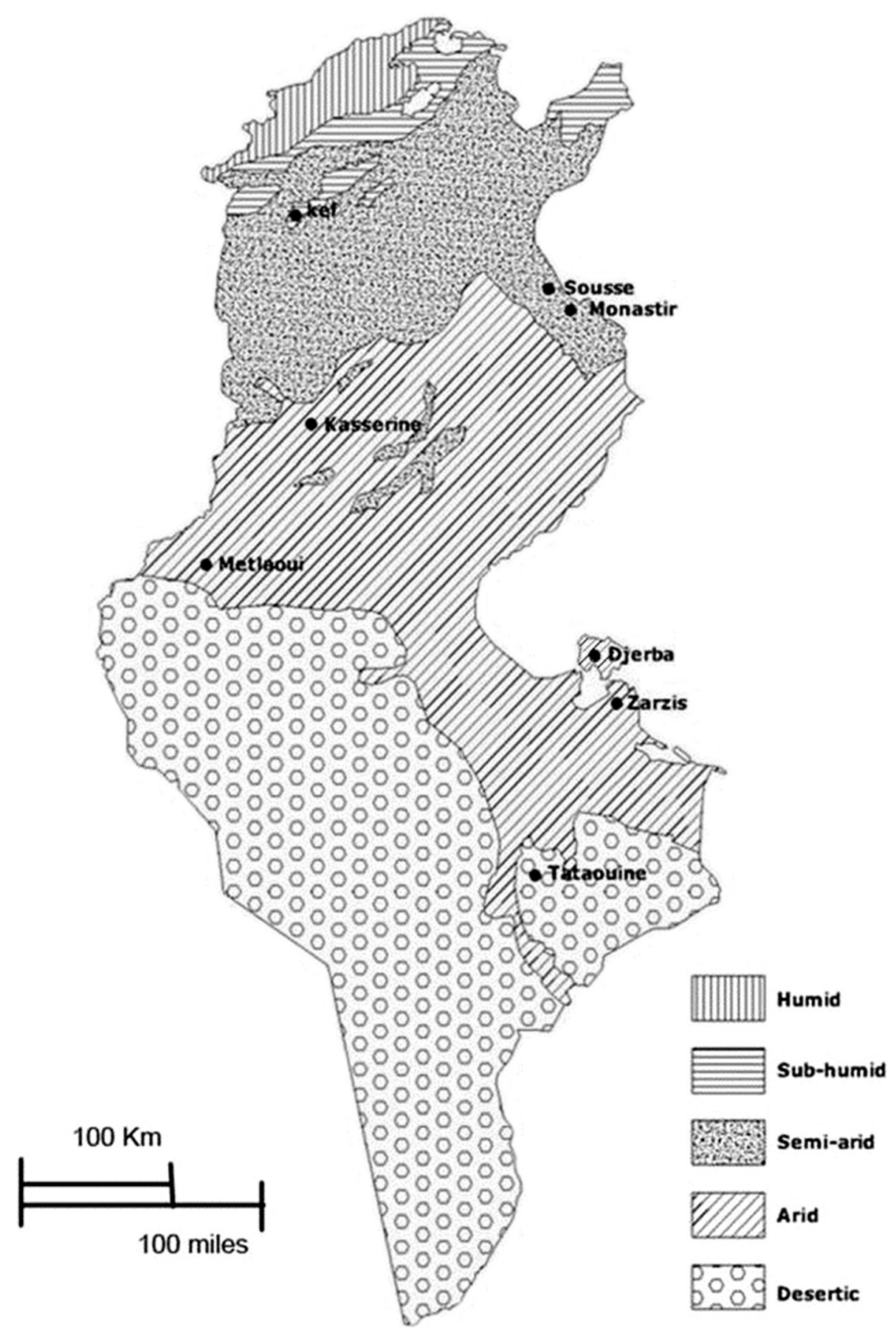

Figure 1 Dog faecal sample collections (eight sites) and their locations within the different climates of Tunisia.

for one hour at $65^{\circ} \mathrm{C}$. Finally, the total DNA was extracted using a phenol-chloroform protocol [38].

\section{PCR amplification}

The E. granulosus DNA was analysed by Eg1121/1122 PCR which amplified a 133 base pairs (bp) fragment of the tandem repeat EgG1HaeIII [39] following the protocol of Naidich et al., [32] modified as follows: the $\mathrm{MgCl}_{2}$ concentration was increased up to $3 \mathrm{mmol} / \mathrm{l}$ and the BSA (Bovine Serum Albumin) $(0.1 \mathrm{mg} / \mathrm{ml})$ was replaced by $1 \%$ formamide solution (Invitrogen). The percentage of dog faeces samples found positive for E. granulosus using PCR diagnostic provided the environmental contamination index by $E$. granulosus. The index of contamination of $E$. granulosus eggs was estimated as the number of PCR positive isolates/total number of examined samples in each 
Table 1 Bioclimatic and geographic characteristics of the studied regions

\begin{tabular}{llllllll}
\hline Region & Area $\left(\mathbf{K m}^{2}\right)$ & Sheepd & Goatd & Cattled & Temp $\left(\mathbf{C}^{\circ}\right)$ & Rain $(\mathbf{m m})$ & Echhuman $(\mathbf{A S I})$ \\
\hline Sousse & 266200 & 0.68 & 0.02 & 0.05 & 18.3 & 300 & 9.88 \\
Monastir & 102400 & 1.17 & 0.03 & 0.14 & 18.3 & 300 & 6.22 \\
Metlaoui & 111335 & 0.16 & 0.00 & 0.00 & 19.3 & 106 & 11.04 \\
Kef & 42890 & 1.51 & 0.10 & 0.09 & 17.0 & 450 & 32.78 \\
Djerba & 53389 & 0.24 & 0.60 & 0.01 & 20.1 & 217 & 1.84 \\
Zarzis & 95862 & 0.21 & 0.10 & 0.00 & 19.8 & 216 & 1.84 \\
Kasserine & 826000 & 0.37 & 0.06 & 0.00 & 17.5 & 318 & 34.32 \\
Tataouine & 380000 & 0.79 & 0.65 & 0.00 & 20.0 & 123 & 0.92 \\
\hline
\end{tabular}

Sheepd: sheep density (number/surface of region), Goatd: goat density, Cattled: cattle density, Temp $\left(C^{\circ}\right)$ : Annual average temperature, Rain(mm): Annual average rainfall, Echhuman: human echinococcosis based on annual surgical incidence (ASI, new cases for 100,000 inhabitants).

region. Eg1121/1122 PCR is the most species-specific for $E$. granulosus but a cross reaction with the Tibetan wildlife species E. shiquicus was noted [40]. This should not be considered as a diagnostic problem since the presence of this species in Tunisia is highly improbable. The expected patterns of the amplification bands demonstrated the tandem arrangement of the EgG1HaeIII repeat. The size of the major bands obtained matched the 133, 402, 671 and $940 \mathrm{bp}$ and minor bands approximately at 300 and $600 \mathrm{bp}$. Amplified bands are larger by increments of 269 bp (the size of the repeat unit) [39]. Because the simultaneous existence of more than one genotype has been described in dogs [41], the PCR-RFLP method of the nad1 gene described by Hüttner et al. [42] was used to identify the genotypes of $E$. granulosus implied. A 1073-1078 bp-long fragment including the complete NADH dehydrogenase subunit 1 (nad1) gene was amplified and subsequently digested with the restriction enzyme HphI (New England BioLabs). The RFLP banding patterns allow a clear discrimination between $E$. granulosus sensu stricto, E. equinus, E. ortleppi, E. canadensis G6/G7 and E. felidis species. The presence of the genotype G1, which is the major genotype in Tunisia, was confirmed using Egss1 PCR [43]. This PCR amplified a mitochondrial sequence of $254 \mathrm{bp}$ encoding the 12S rRNA small subunit.

\section{Statistical analyses \\ Characteristics of regions}

The relationships between characteristics were established using non-parametric Spearman rank correlations. The contamination index of dog faeces and incidence in humans (the number of new cases per year), climatic characteristics and livestock density of studied regions were analysed using a principal component analysisPCA with MVSP software (Multivariate statistical package. MVSP. User' manual. Version 3.1. KCS, 288. Pentraeth, Wales, UK. 2002). The inertia values of each axis represented the percentage of variance, e.g. the explanatory power of the analysis. The end of vector (variable) location was indicative of its importance: at the intersection of the two axes it means that it has no explanatory power whereas when located far from the origin it means it is an important variable in the system. If variables were located in the same area of the graph, it indicates they were highly similar and positively related, if the variables were located in the opposite parts of the graph, they were negatively related. The annual surgical incidence [6] in humans and the dog faecal contamination index observed here were compared against climatic and geographic characteristics of studied regions $[44,45]$ (Table 1). The contamination indices of faeces of the eight regions were analysed with Chi-square test (significance level at $\mathrm{p}<0.05$ ).

\section{Construction of genetic distances and reticulograms}

The six bands from PCR 1121/1122 were each coded as present or absent for each E. granulosus egg isolate (MVSP 3.1, 2002). The average of Jaccard similarities of egg isolate banding patterns were calculated within and between regions. These average similarities were transformed into distances (as 1- average Jaccard similarity). T-REX software was used for constructing reticulograms of the genetic distance matrix [46]. The ADDTREE is one of the most frequently used methods for inferring phylogenetic trees. It reconstructs a phylogenetic tree structure starting from a star tree that contains $n$ leaves associated with the objects and n-1 edges. The star tree is repeatedly developed by adding new internal nodes to it until a binary tree comprising of $2 \mathrm{n}-2$ nodes (including $\mathrm{n}$ leaves and $\mathrm{n}-2$ internal nodes) and $2 \mathrm{n}-3$ edges is obtained [47]. A classical Neighbour joining reticulogram (NJ) was also constructed. Furthermore, a Mantel test was applied to show if there was any significant correlation between the genetic and geographic distances between studied areas using GENETIX software [48]. 


\section{Results}

\section{Contamination index}

Among the 1095 faecal samples, 298 samples contained taeniid eggs. The ninety-three percent of taeniid samples (277 isolates) were identified as E. granulosus eggs. The banding patterns of the Eg1121/1122 PCR revealed profiles composed of one to six bands (133, 300, 402, 600, 671 and $940 \mathrm{bp}$ ) (Figure 2). The molecular analysis by PCR-RFLP of the nad1 gene produced identical patterns (four fragments of 485, 320, 204 and $63 \mathrm{bp}$ ) for all samples tested corresponding to E. granulosus sensu stricto profile (Figure 3). The overall contamination index of dog faeces by E. granulosus was 25.3\% (277/1095) and different infection levels were observed between regions $(\mathrm{p}=0.0006)$. The Metlaoui region had a significantly higher index than all other regions, followed by Djerba (Table 2). The other regions were similar.

\section{Characteristics of the studied regions}

The observed bioclimatic and geographic characteristics of the studied regions as well as sheep, goats and cattle densities and the prevalence of dog and human echinococcosis can be seen in Tables 1 and 2. The sheep density and to a lesser extent the cattle density, were negatively correlated to dog echinococcosis $(\mathrm{p}=0.03)$ (Figure 4). The human echinococcosis incidence was significantly and negatively correlated to temperature $(\mathrm{p}=0.001)$ and positively to rain $(\mathrm{p}=0.03)$ (Figure 5). By including geographic and endemic/enzootic data in MVSP software, the PCA graphics showed the relationship of echinococcosis in dogs (echdog) and hydatidosis in humans (echhuman) (Figures 4 and 5) under natural conditions in the studied regions. $\mathrm{CE}$ in humans was more endemic in humid areas unlike canine echinococcosis which remained endemic even in arid regions. No relationship was observed between the contamination index of dogs and the livestock density within the regions studied.

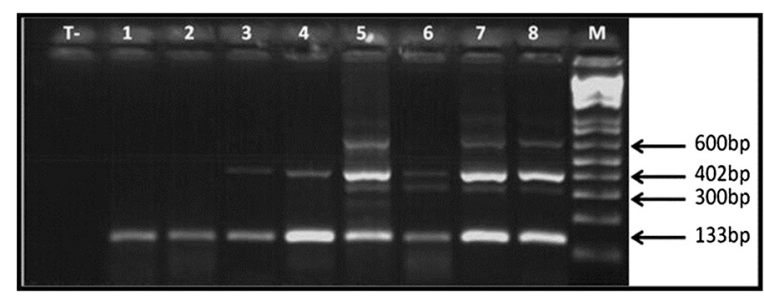

Figure 2 PCR banding patterns derived from E. granulosus eggs demonstrated the genetic polymorphisms of the EgG1Haelll repeat. Lane T-: negative control, lanes 1,2: one band profiles (133 bp), lane 3,4: two bands profiles (133 bp, $402 \mathrm{bp}$ ), lanes 5, 7,8: four bands profiles (133 bp, 402 bp, 600 bp, 671 bp), lane 6: three bands profiles (133 bp, 402 bp, 600 bp), lane M: 100-bp DNA ladder marker (Promega).

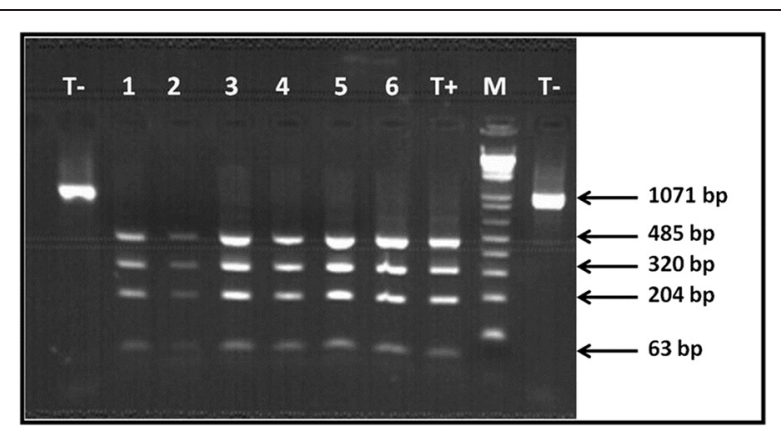

Figure 3 Restriction fragment length polymorphism analysis of nad1 gene amplified product. Lane T-: negative control (indigested nad1 PCR product), lanes 1-6: Identical patterns (485, 320, 204 and $63 \mathrm{pb}$ fragments) for samples with one to six band profiles in 1121/ 1122 PCR, lane M: 1 Kb Plus DNA ladder marker (Invitrogen).

\section{Genetic differentiation}

The reticulograms by T-REX software using ADDTREE and Neighbour Joining methods on genetic distance matrix gave slightly different distributions (Figure 6). Two different stable groups were found in both reticulograms: Tataouine-Kasserine and Kef-Metlaoui. No significant correlation between the genetic distances based on PCR Eg1121/1122 results and the geographic distances was observed using the Mantel test $(r=0.06)$ (Figure 7).

\section{Discussion}

The contamination index of dog faeces by E. granulosus eggs ranged from $8.3 \%$ to $41.3 \%$ depending on the region. The contamination index falls within the same range (prevalence: $9 \%$ to $41 \%$ ) that was reported by Bentounsi et al. [49] in eastern Algeria based on necropsies in a similar environment. Similar values were also found in other neigbouring countries (Egypt, Lybia or Morocco) [8]. The PCA analyses based on human surgical incidence [6] and dog contamination index did not find the two to be related. Indeed, regions with high levels of canine echinococcosis have previously been found to be meso or hypoendemic for human echinococcosis (Metlaoui, Djerba and Zarsis). Moreover, hyper-endemic areas for hydatidosis, such as Kef, showed a low contamination index by E. granulosus eggs in dog faeces. Despite that dogs are involved in the parasite transmission, many other factors influence the human infestation, such as livestock management practices, hygiene levels, health education and finally lack of knowledge about the parasite life-cycle in the local population [19]. Home slaughtering is still practiced without any municipal veterinary supervision and it is probably an important source for dog infection. It should also be noted that the human incidence data used here was obtained few years before the present investigation. It is thus possible that the present human echinococcosis prevalence 
Table 2 E. granulosus contamination index of dog faeces in relation to regions

\begin{tabular}{|c|c|c|c|c|c|c|c|c|}
\hline Region & $\begin{array}{l}\text { Sousse } \\
n=81\end{array}$ & $\begin{array}{l}\text { Monastir } \\
\mathrm{n}=95\end{array}$ & $\begin{array}{l}\text { Kasserine } \\
\mathrm{n}=132\end{array}$ & $\begin{array}{l}\text { Kef } \\
n=36\end{array}$ & $\begin{array}{l}\text { Djerba } \\
n=127\end{array}$ & $\begin{array}{l}\text { Zarsis } \\
\mathrm{n}=129\end{array}$ & $\begin{array}{l}\text { Metlaoui } \\
\mathrm{n}=392\end{array}$ & $\begin{array}{l}\text { Tataouine } \\
n=103\end{array}$ \\
\hline \% of E. granulosus positive dog faeces & $12.3^{\mathrm{a}}$ & $9.5^{\mathrm{a}}$ & $18.2^{\mathrm{a}}$ & $8.3^{a}$ & $27.6^{\mathrm{b}}$ & $17.8^{a}$ & $41.3^{c}$ & $14.6^{\mathrm{a}}$ \\
\hline
\end{tabular}

$\mathrm{n}=$ number of samples analyse.

The supercripts a, b, c indicate significant differences using Chi-square test, the level of significance was set at $p<0.05$.

may have since changed [6]. The presence of E. granulosus eggs in the dog faeces was observed to spread without positive relation to livestock density of the studied regions (see Figure 4), showing a higher contamination index in isolates of warmer regions. The development of the dog parasite in dry areas with a limited number of herbivores might be related to the canine high densities in these regions ( $>1$ per 5 inhabitants) rather than to climatic conditions since the survival of eggs is favored in humid areas [50]. The high contamination index of dog faeces observed in Djerba island (hydatidosis hypoendemic area) was unexpected. This may be due to the growing number of imported watchdogs into Djerba which defecated in the environment without faeces being collected. As reported by Kamiya et al. [51] in Japan islands, the moving of dogs from one place to another increases the risk of environmental contamination by Echinococcus eggs in uninfected or hypoendemic areas. In the present study, only the $E$. granulosus G1 genotype was found. Nevertheless, genetic polymorphisms were observed between these G1 isolates by the use of 1121/1122 PCR. The genetic distances were not related to geographic distances, which is indicative of local divergent evolutions rather than isolation by distance. This is in agreement with those reported by Oudni-M'rad et al. [52,53] who described significant genetic variation within the G1 genotype isolates of Sousse and Gafsa in Tunisia based on different genetic markers. No genetic structuration (genetic differences between regions) due to geographic distance could be found by the use of the Mantel test nor the TEX trees in NJ or the ADD tree applications. The G1 isolates could be alike in different regions since the intermediate hosts are transported from one farming region to another (slaughterhouse or livestock market).

\section{Conclusion}

The relationship between human and dog infections is difficult to trace because a high environmental dog contamination index does not necessarily correspond to high prevalence in humans as transmission is strongly linked to human behavior and hygiene.

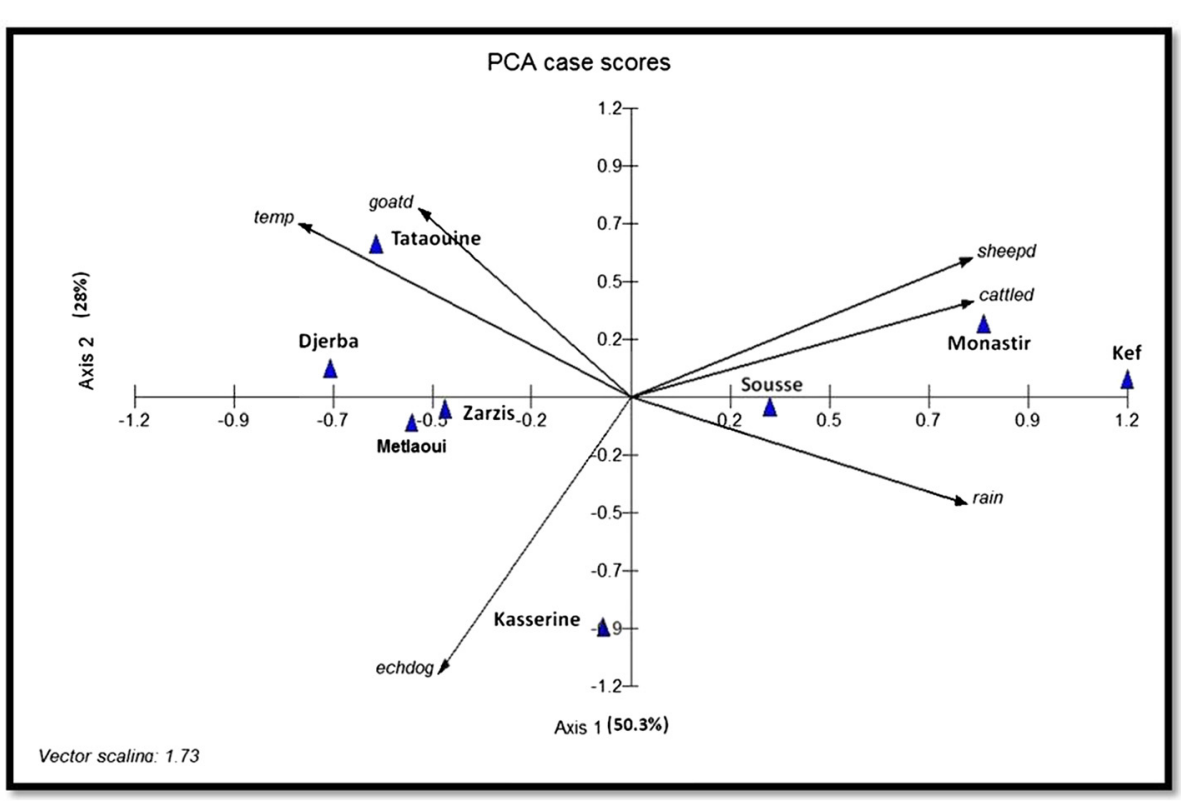

Figure 4 Dog echinococcosis and Tunisian region characteristics described by principal component analysis. echdog: dog faeces contamination index by E. granulosus eggs, temp: average yearly temperature, rain: average yearly rainfall, sheepd: sheep density (number/surface of region), cattled: cattle density, goatd: goat density. 


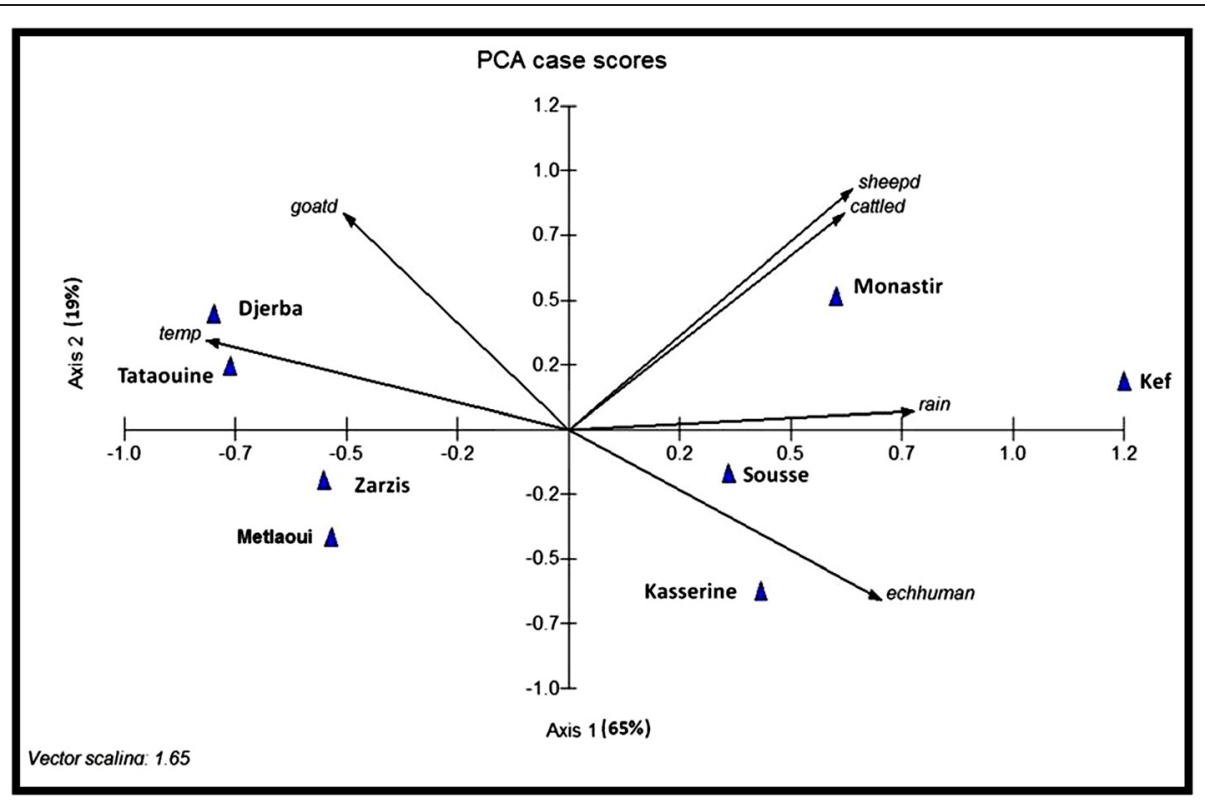

Figure 5 Human echinococcosis and Tunisian region characteristics described by principal component analysis. echhuman: human echinococcosis according to the annual surgical incidence, temp: average yearly temperature, rain: average yearly rainfall, sheepd: sheep density (number/surface of the region), cattled: cattle density, goatd: goat density.

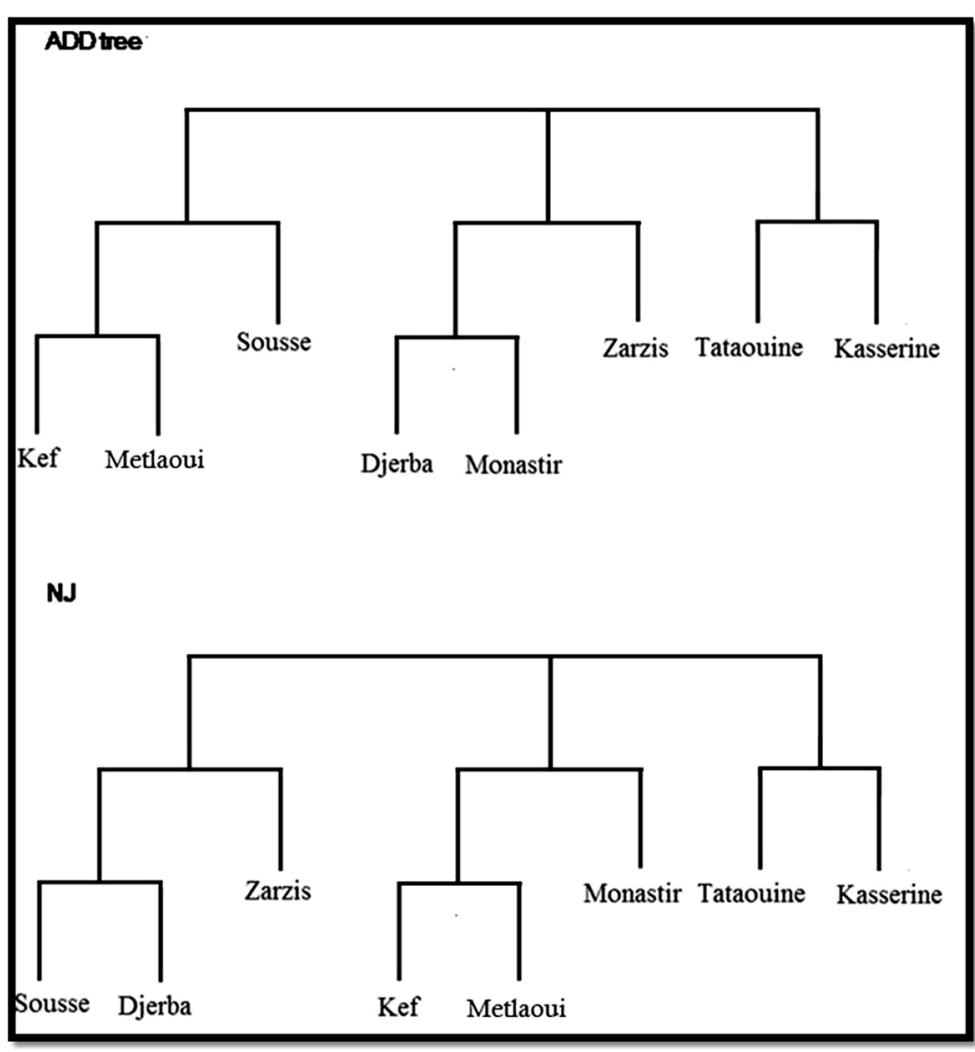

Figure 6 T-REX reticulograms with ADD tree and Neigbour Joining (NJ) methods based on genetic distances of the E. granulosus egg isolates of eight Tunisian regions. 


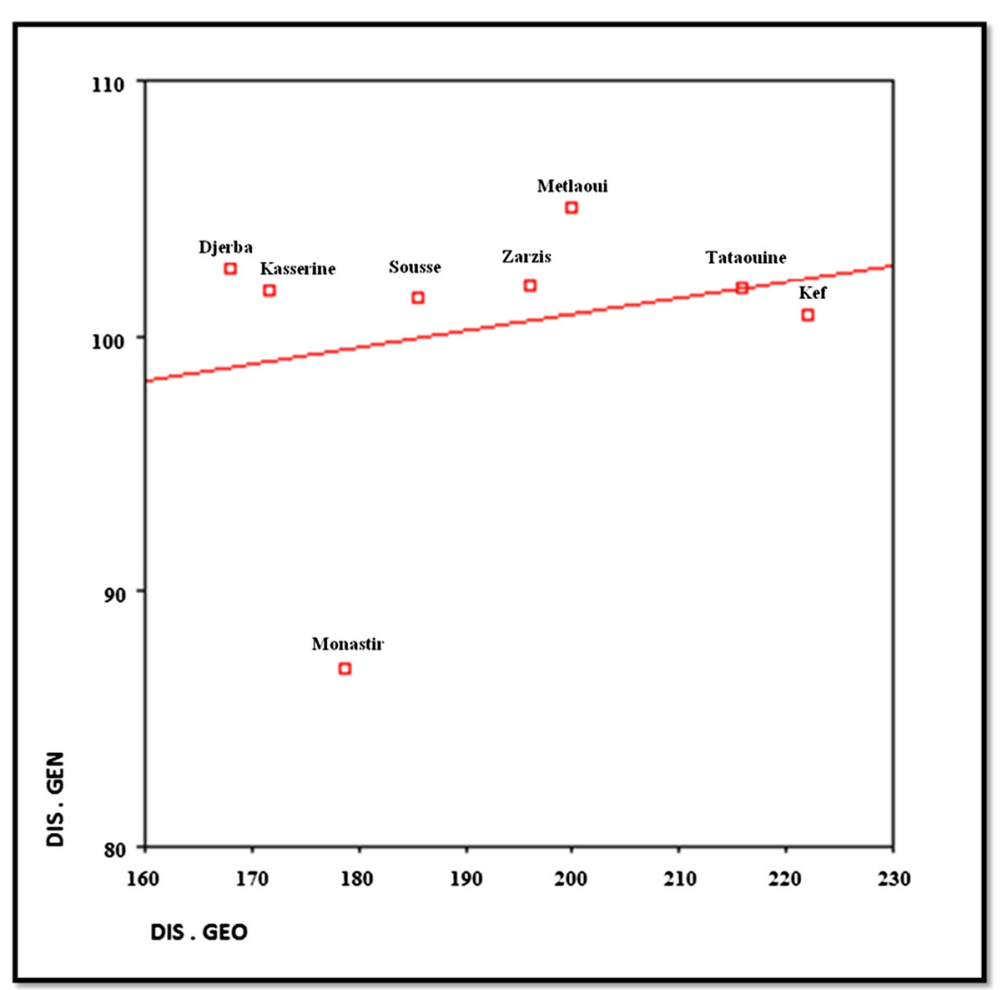

Figure 7 Genetic differentiation by distance (Mantel test). Average DIS. GEN for one site: Genetic distances, Average DIS. GEO for one site: Geographic distances in km.

\section{Competing interests}

The authors declare that they have no competing interests.

\section{Authors' contributions}

RCB: contributed to the acquisition of data, carried out the molecular genetic studies and have been involved in drafting the manuscript. MOM: participated in the design of the study, contributed to data collection and helped to draft the manuscript. JC: performed the statistical analysis and have been involved in revising critically the manuscript for important intellectual content. SM: participated in the coordination of the study, the data collection and revised critically the manuscript. HM: participated in caring out the molecular genetic studies. HB: participated in the design of the study and have been involved in revising critically the manuscript. All authors read and approved the final version of the manuscript.

\section{Acknowledgements}

We thank the Tunisian Ministry of Higher Education and Scientific Research for their financial support. We are grateful to Elizabeth Tchaicha for her assistance with the linguistic part of this paper, Caroline Chylinski for comments and last check of the manuscript and to Mohamed Mourad Chaabane for technical help.

\section{Author details}

'LP3M: Laboratoire de Parasitologie-Mycologie Médicale et Moléculaire, LR12ES08, Faculté de Pharmacie, Université de Monastir, 1 rue Avicenne, Département de biologie clinique B, 5000 Monastir, Tunisie. ${ }^{2}$ INRA and Université F. Rabelais, UMR 1282, Infectiologie et santé publique, 37380 Nouzilly, France. ${ }^{3}$ Laboratoire de parasitologie, E.P.S F. Bourguiba, 5000 Monastir, Tunisie.

Received: 2 February 2015 Accepted: 29 March 2015

Published online: 17 April 2015

\section{References}

1. Battelli G. Echinococcosis: costs, losses and social consequences of a neglected zoonosis. Vet Res Commun. 2009;33:47-52.

2. Budke CM, Deplazes P, Torgerson PR. Global Socioeconomic Impact of Cystic Echinococcosis. Emerg Infect Dis. 2006;12(2):296-303.

3. Carmena D, Cardona GA. Canine echinococcosis: Global epidemiology and genotypic diversity. Acta Trop. 2013;128:441-60.

4. Adanir R, Tasci F. Prevalence of helminth eggs in raw vegetables consumed in Burdur, Turkey. Food Control. 2013;31:482-4.

5. Eckert TJ, Deplazes P. Biological, epidemiological, and clinical aspect of Echinococcosis, a zoonosis of increasing concern. Clin Microbiol Rev. 2004;17(1):107-35

6. Chahed MK, Bellali H, Touinsi H, Cherif R, Ben Safta Z, Essoussi M, et al. Distribution of surgical hydatidosis in Tunisia, results of 2001-2005 study and trends between 1977 and 2005. Arch Inst Pasteur Tunis. 2010;87(1-2):43-52.

7. Majorowski MM, Carabin H, Kilani M, Ben SA. Echinococcosis in Tunisia: a cost analysis. Trans R Soc Trop Med Hyg. 2005;99:268-78.

8. Dakkak A. Echinococcosis/hydatidosis: A severe threat in Mediterranean countries. Vet Parasitol. 2010;174:2-11.

9. Centralized Information System for Infectious Diseases, Communicable Diseases, Surveillance and Response. WHO Regional Office for Europe, Copenhagen, Denmark. 2014. http://data.euro.who.int/cisid.

10. Brundu D, Piseddu T, Stegel G, Masu G, Ledda S, Masala G. Retrospective study of human cystic echinococcosis in Italy based on the analysis of hospital discharge records between 2001 and 2012. Acta Trop. 2014;140:91-6.

11. Hüttner M, Nakao M, Torsten W, Siefert L, Boomker JDF, Dinkel A, et al. Genetic characterization and Phylogenetic position of Echinococcus felidis (Cestoda :Taeniidae) from the African lion. Int J Parasitol. 2008:38:861-8.

12. Nakao M, McManus DP, Schantz PM, Craig PS, Ito A. A molecular phylogeny of the genus Echinococcus inferred from complete mitochondrial genomes. Parasitology. 2007;134(Pt5):713-22.

13. Nakao M, Yanagida T, Okamoto M, Knapp J, Nkouawa A, Sako Y, et al. State-ofthe-art Echinococcus and Taenia: Phylogenetic taxonomy of human- 
pathogenic tapeworms and its application to molecular diagnosis. Infect Genet Evol. 2010;10(4):444-52

14. Lahmar S, Debbek H, Zhang LH, McManus DP, Souissi A, Chelly S, et al. Transmission dynamics of the Echinococcus granulosus sheep-dog strain (G1 genotype) in camels in Tunisia. Vet Parasitol. 2004;121:151-6.

15. M'rad S, Filisetti D, Oudni M, Mekki M, Belguith M, Nouri A, et al. Molecular evidence of ovine (G1) and camel (G6) strains of Echinococcus granulosus in Tunisia and putative role of cattle in human contamination. Vet Parasitol. 2005; 129:267-72.

16. M'rad S, Oudni-M'rad M, Filisetti D, Mekki M, Nouri A, Sayadi T, et al. Molecular identification of Echinococcus granulosus in Tunisia : first record of the buffalo strain (G3) in human and bovine in the country. Open Vet Sci J. 2010;4:27-30.

17. Boufana B, Lahmar S, Rebaï W, Ben Safta Z, Jebabli L, Ammar A, et al. Genetic variability and haplotypes of Echinococcus isolates from Tunisia. Trans R Soc Trop Med Hyg. 2014;108(11):706-14.

18. Lahmar S, Trifi M, Ben Naceur S, Bouchhima T, Lahouar N, Lamouchi I, et al. Cystic echinococcosis in slaughtered domestic ruminants from Tunisia. J Helminthol. 2013;87(3):318-25.

19. Aoun $\mathrm{K}$, Bouratbine A. Epidemiological data concerning hydatidosis in Tunisia. Med Mal Infect. 2007;37:40-2.

20. Food and Agriculture Organization of the United Nations. Renforcement de la surveillance et des systèmes d'alerte pour la fièvre catarrhale ovine, la fièvre du Nil occidental et la rage au Maroc, en Algérie et en Tunisie. 2009. p. 17p. Projet GCP/RAB/002/FRA.

21. Lahmar S, Kilani M, Torgerson PR. Frequency distribution of Echinococcus granulosus and other helminths in stray dogs in Tunisia. Ann Trop Med Parasitol. 2001;95:69-76.

22. Lahmar S, Boufana B, Lahmar S, Inoubli S, Guadraoui M, Dhibi M, et al. Echinococcus in the wild carnivores and stray dogs of northern Tunisia: the results of a pilot survey. Ann Trop Med Parasitol. 2009;103:323-31.

23. Sanchez-Thevenet $P$, Jensen $O$, Drut $R$, Cerrone GE, Grenóvero MS, Alvarez $H M$, et al. Viability and infectiousness of eggs of Echinococcus granulosus aged under natural conditions of inferior arid climate. Vet Parasitol. 2005;133:71-7.

24. Cabrera M, Canova S, Rosenzvit M, Guarnera E. Identification of Echinococcus granulosus eggs. Diagn Microbiol Infect Dis. 2002;44:29-34.

25. Torgerson PR, Heath DD. Transmission dynamics and control options for Echinococcus granulosus. Parasitology. 2003;127:143-58.

26. Seimenis A. Overview of the epidemiological situation on echinococcosis in the Mediterranean region. Acta Trop. 2003;85:191-5.

27. Azlaf R, Dakkak A, Chentoufi A, El Berrahmani M. Modelling the transmission of Echinococcus granulosus in dogs in the northwest and in the southwest of Morocco. Vet Parasitol. 2007;145:297-303.

28. Benito A, Carmena D. Double-antibody sandwich ELISA using biotinylated antibodies for the detection of Echinococcus granulosus coproantigens in dogs. Acta Trop. 2005;95:9-15.

29. Barnes TS, Deplazes P, Gottstein B, Jenkins DJ, Mathis A, Siles-Lucas M, et al. Challenges for diagnosis and control of cystic hydatid disease. Acta Trop. 2012;123:1-7.

30. Eckert J. Predictive values and quality control of techniques for the diagnosis of Echinococcus multilocularis in definitive hosts. Acta Trop. 2003;85:157-63.

31. Mathis A, Deplazes P. Copro-DNA tests for diagnosis of animal taeniid cestodes. Parasitol Int. 2006;55(Suppl):S87-90.

32. Naidich A, McManus DP, Canova SG, Gutierrez AM, Zhang W, Guarnera EA et al. Patent and pre-patent detection of Echinococcus granulosus genotypes in the definitive host. Mol Cell Probes. 2006;20:5-10.

33. Pan D, De S, Bera AK, Bandyopadhyay S, Das SK, Bhattacharya D. Molecular differentiation of cryptic stage of Echinococcus granulosus and Taenia species from faecal and environmental samples. Asian Pac J Trop Med. 2010;3:253-6.

34. Eckert TJ, Gottstein B, Heath D, Liu FJ. Prevention of echinococcosis in humans and safety precautions. In: Eckert TJ, Gemmell MA, Meslin FX, Pawłowski ZS, editors. WHO/OIE Manual on Echinococcosis in Humans and Animals: a Public Health Problem of Global Concern. Paris: WHO; 2001. p. 96-105.

35. Dryden MW, Payne PA, Ridley R, Smith V. Comparison of common fecal flotation techniques for the recovery of parasite eggs and oocysts. Vet Ther. 2005;6(1):15-28

36. Morseth DJ. Ultrastructure of developing taeniid embryophores and associated structures. Exp Parasitol. 1965:16:207-16.
37. Bretagne S, Guillou JP, Morand M, Houin R. Detection of Echinococcus multilocularis DNA in fox faeces using DNA amplification. Parasitology. 1993;106:193-9.

38. Sambrook J, Fitsch EF, Maniatis T. Molecular Cloning: A Laboratory Manual. 2nd ed. New York: Cold Spring Harbor, Laboratory Press; 1989.

39. Abassi I, Branzburg A, Campos-Ponce M, Abdel Hafez SK, Raoul F, Craig PS. Copro-Diagnosis of Echinococcus granulosus infection in dogs by amplification of newly identified repeated DNA sequence. Am J Trop Med Hyg. 2003;69(3):324-30.

40. Boufana BS, Campos-Ponce M, Naidich A, Buishi I, Lahmar S, Zeyhle E, et al. Evaluation of three PCR assays for the identification of the sheep strain (genotype 1) of Echinococcus granulosus in canid feces and parasite tissues. Am J Trop Med Hyg. 2008;78(5):777-83.

41. Lymbery AJ, Thompson RCA, Lachberg S, Yap KW. Biochemical and molecular identification of species of Taenia. Aus Vet J. 1989;66(7):227.

42. Hüttner M, Siefert L, Mackenstedt U, Romig T. A survey of Echinococcus species in wild carnivores and livestock in East Africa. Int J Parasitol. 2009;39:1269-76.

43. Dinkel A, Njoroge EM, Zimmermann A, Wälz M, Zeyhle E, Elmahdi IE, et al. A PCR system for detection of species and genotypes of the Echinococcus granulosus-complex, with reference to the epidemiological situation in eastern Africa. Int J Parasitol. 2004:34:645-53.

44. Information system on desertification in Tunisia. Gafsa, Kasserine, Kef, Medenine, Tataouine. Tunisian ministry of environment, Tunis. 2006. http:// www.environnement.nat.tn/envir/sid/

45. Maher M. Le climat agricole au Sahel Tunisien et les changements climatiques. In Université du Québec à Montréal; 2009. http://www.archipel.uqam.ca/2466/.

46. Makarenkov $V$, Legendre $P$. Improving the additive tree representation of a dissimilarity matrix using reticulations. In: Kiers HAL, Rasson JP, Groenen PJF, Schader M, editors. Data Analysis, classification and related Methods. New York: Springer; 2000. p. 35-40.

47. Sattath S, Tversky A. Additive similarity trees. Psychometrika. 1977;42:319-45.

48. Belkhir K, Borsa P, Goudet J, Chikhi L, Bonhomme F. GENETIX 4.05, logiciel sous Windows TM pour la génétique des populations. Laboratoire Génome, Populations, Interactions, CNRS UMR 5000. Montpellier, France: Université de Montpellier II; 2003.

49. Bentounsi B, Meradi S, Ayachi A, Cabaret J. Cestodes of untreated large stray dog populations in Algeria: a reservoir for herbivore and human parasitic diseases. Open Vet Sci J. 2009;3:64-7.

50. Jenkins EJ, Schurer JM, Gesy KM. Old problems on a new playing field: Helminth zoonoses transmitted among dogs, wildlife, and people in a changing northern climate. Vet Parasitol. 2011;182:54-69.

51. Kamiya M, Lagapa JTG, Nonaka N, Ganzorig S, Oku Y, Kamiya H. Current control strategies targeting sources of echinococcosis in Japan. Rev Sci Tech. 2006;25(3):1055-66

52. Oudni-M'rad M, M'rad S, Mekki M, Belguith M, Cabaret J, Pratlong F, et al Genetic relationships between sheep, cattle and human Echinococcus infection in Tunisia. Vet Parasitol. 2004;121:95-103.

53. Oudni-M'rad M, Cabaret J, M'rad S, Bouzid W, Mekki M, Belghith M, et al. Genetic differences between Tunisian Camel and Sheep strains of the Cestode Echinococcus granulosus revealed by SSCP. Parasite. 2006;13:131-6.

\section{Submit your next manuscript to BioMed Central and take full advantage of:}

- Convenient online submission

- Thorough peer review

- No space constraints or color figure charges

- Immediate publication on acceptance

- Inclusion in PubMed, CAS, Scopus and Google Scholar

- Research which is freely available for redistribution 